\title{
KRONIK
}

\section{Ny arbejdslivsbalancer under corona-krisen - muligheder og udfordringer for ledelse og medarbejdere}

\author{
Steen E. Navrbjerg \& Dana Minbaeva
}

Keywords: Virtuel ledelse, Covid-19, arbejdslivsbalancer, corona-forskning

\section{Introduktion}

Da Danmark lukkede ned i midten af marts 2020, skulle mange arbejdspladser på kort tid omstrukturere deres ledelse og samarbejde. Særligt distanceledelse var for mange ledere og medarbejdere en ny udfordring - og selv på arbejdspladser, hvor man fra tid til anden allerede havde arbejdet med virtuel ledelse og samarbejde, var det nyt at have virtuelle medier som det eneste ledelsesredskab.

Når en altomfavnende krise manifesterer sig, bliver kvaliteter såvel som mangler i ledelse særligt tydelige. Corona-krisen har således været en prisme, hvorigennem vi kan betragte ledelse og arbejde i et nyt lys, og dermed også et værktøj, som kan bruges til at revurdere ledelse såvel som vores forståelse af arbejdets natur.

Helt overordnet stiller vores erfaringer fra ledelse og arbejdsliv under corona spørgsmålstegn ved den traditionelle organisering af arbejdet, som stadig mange steder er bundet op på fysisk tilstedeværelse på arbejdspladsen. Spørgsmålet er, hvilke nye arbejdslivsbalancer, coronaen har åbnet muligheder for - og om der er faldgruber i de nye muligheder.

\section{Corona-forskning \\ - en særlig disciplin}

Når en så epokegørende begivenhed som corona-krisen sætter ind, må man som arbejdsmarkedsforsker revurdere sit arbejde: Er de projekter, man sidder med netop nu, overhovedet relevante, når arbejdsliv og ledelse måske omkalfatres grundlæggende i løbet af få måneder? Eller er corona-krisen bare en krusning på overfladen, hvorefter vi går tilbage til normalen få måneder senere?

Disse overvejelser gennemgik vi også umiddelbart efter nedlukningen i marts 2020. Meget hurtigt fornemmede vi dog, at noget særligt var på spil: Vi hørte om ledere, 
som var udfordret af at skulle lede virtuelt, som havde svært ved at styre møder, og som kun vanskeligt kunne opretholde deres ledelsesautoritet i de virtuelle møder.

Dette blev udgangspunktet for forskningsprojektet 'Virtuel ledelse under corona-krisen', som blev udviklet på seks dage fra 27. marts til 3. april og som modtog fondsmidler fra Innovationsfonden den 15. april 2020.

Med den hastighed er det oplagt, at vi som forskere kun havde en meget vag idé om, hvad vi ville møde, når vi skulle bedrive forskning midt under en hård nedlukning af Danmark. Hvad ville være de afgørende udfordringer for ledelse og arbejdsliv under corona-nedlukningerne? Vi havde ingen fortilfælde for en situation, hvor så store andele af arbejdsmarkedet med dags varsel skulle overgå til hjemmearbejde og virtuel ledelse - i første omgang i flere uger, men meget hurtigt blev det klart, at der ville blive tale om måneder.

Udgangspunktet for forskningsprojektet var tre faser:

- En fase under nedlukningen i foråret 2020, bestående af interviews med arbejdsgiverrepræsentanter samt ledelse og medarbejdere på 18 virksomheder (i alt 36 interview);

- en fase i eftersommeren 2020, bestående af en spørgeskemaundersøgelse om, hvor udbredte de fundne resultater fra interviewundersøgelsen var (i alt 594 svar på 1041 udsendte spørgeskemaer; svarprocent 57 );

- en fase i efteråret 2020, bestående af interviews med de samme personer som $\mathrm{i}$ foråret om, hvad man havde taget med ledelsesmæssigt og organisatorisk, nu hvor corona-krisen var overstået.

Som vi alle ved i dag, var corona på ingen måde overstået i efteråret 2020; tværtimod bevægede vi os ind i en 2 . nedlukning, som tydeligvis ville vare mange måneder. At coronaen ikke opførte sig som forventet, fik stor indflydelse på forskningsprocessen. Projektdesignet måtte hele tiden ændres, fordi objektet kontant flyttede sig - og det fik stor indflydelse på forskningsprocessen.

Reelt var der to valgmuligheder: Enten at udskyde tredje fase af undersøgelsen til efter corona - eller at gennemføre interviewrunden, men ændre formålet til at belyse, hvordan man tacklede 2 . nedlukning, herunder om fokus i ledelse havde ændret sig. En afgørende præmis ved projektet var at 'levere forskning til tiden' - det vil sige hurtig viden om ledelse under corona, som kunne bruges af ledere og medarbejdere under og efter nedlukning. Derfor valgte vi den første løsning - at interviewe så mange som muligt endnu en gang om oplevelserne med ledelse og organisering i efteråret 2020 (i alt 28 interview).

Dermed har forskningsprocessen været meget anderledes end normalt; forskningsobjektet har været et moving target, og det har fordret stadige ændringer i forskningsdesignet. Men samtidig har det også skabt en livlig dialog mellem forskere og forskningsobjekt.

Det har i høj grad været forskningsobjektet, der har fået lov at styre forskningsprojektet. Med det menes, at vi i interviewene - især i foråret - var meget åbne. Dermed blev det i høj grad det, der lå interviewpersonerne på sinde midt i det kaos, som en corona-nedlukning er, der blev styrende for afrapporteringen.

Valget om at lade interviewpersoner være styrende for de emner, der blev taget op, var betinget af to forhold: For det første vidste vi ikke med sikkerhed, hvad vi egentlig skulle fokusere på. Vi vidste noget om distanceledelse, vi vidste noget om, hvad der sker, når ledelse bliver mindre tæt - men aldrig før har der været sådanne organisationsændringer pålagt af 'skæbnen' og aldrig så uforberedt som under corona. Det var således en markant anderledes og mere dybtgående organisationsændring, end hvad der hidtil er forsket i. For det andet var det rent pragmatisk; det var en ambition, at resultater fra undersøgel- 
sens første fase skulle være tilgængelige for offentligheden allerede i juni 2020, altså 10 uger efter projektets start - og med så snæver en tidsramme fravalgtes udvikling af en større teoriramme.

I praksis betød det, at interviewpersonerne blev meget styrende for emnerne - men når bestemte emner dukkede op i de første 3-4 interview, forfulgte vi dem så også i de næste interviews. I den forstand blev interviewene mere styrede med tiden - men til stadighed med åbenhed for nye emner. Et eksempel på, hvor styrende interviewpersonerne blev, var emnet produktivitet. Vi havde ikke i vores spørgeguide forberedt spørgsmål, der direkte adresserede produktiviteten - men i alle interview var det den høje produktivitet under corona-hjemmearbejdet, der overraskede lederne mest. Derfor blev dette naturligt nok et væsentligt emne under afrapporteringen - og ydermere kan det tørt konstateres, at uden en høj og for ledelsen tilfredsstillende produktivitet under krisens hjemmearbejde, så ville vi ikke i dag diskutere, om medarbejdere skal arbejde hjemme to, tre eller fire dage om ugen.

Hvor projektet som udgangspunkt havde virtuel ledelse som omdrejningspunkt, så udviklede det sig hurtigt til også at dreje sig om konkrete arbejdsorganiseringer - og ikke mindst trivsel. Corona-nedlukningerne betød, at både ledere og medarbejdere kom til nye erkendelser om, hvordan arbejdet kunne organiseres på andre måder, som både kunne skabe arbejdsglæde, kreativitet og bedre arbejdslivsbalancer. Men opmærksomheden er også blevet skærpet på, hvor meget det sociale betyder, både for individuel trivsel og for arbejdspladsens sammenhængskraft.

I kronikken her fremlægger vi de - med vores øjne - mest interessante resultater fra projektet, som både vedrører ledelse og medarbejdere. Vi runder af med refleksioner over, hvad corona-nedlukningerne fortæller os om ændrede arbejdslivsbalancer. Erfaringerne herfra stiller nemlig overordnet set spørgs- målstegn ved de senere årtiers diskussioner om balancen mellem fritid og arbejdsliv - og om det grænseløse arbejde også har nogle kvaliteter for den enkelte medarbejder.

\section{Foråret 2020 - drift, og hvad med produktiviteten?}

Den første nedlukning i foråret 2020 var præget af tre faser. Inden vi går ind i de tre faser, skal det understreges, at ingen jo som udgangspunkt vidste, hvor lang tid nedlukningen ville vare. Når vi således her formulerer det som den første nedlukning, så kan vi jo kun gøre det med det overblik, vi har nu - hvor vi véd, at der kom endnu en nedlukning. Langt de fleste forventede en relativt kort nedlukning, hvorefter vi alle ville vende tilbage til normalen - først senere måtte vi erkende, at forløbet blev markant anderledes.

\section{Fase 1: Fokus på drift og produktivitet - og en udfordret ledelse}

Da regeringen lukkede Danmark ned 11. marts 2020, var det i første omgang for to uger. Offentligt ansatte blev sendt hjem, og skoler blev lukket. For de direkte berørte handlede det om på ganske kort tid at få tingene til at fungere: Hvordan får den enkelte fat i sin PC, hvordan skal man servicere klienter i det offentlige, hvordan skal man undervise online etc. Med andre ord var fokus i høj grad på drift - den arbejdsmæssige hverdag skulle fungere, mens udvikling blev sat på stand-by. Et helt afgørende fokuspunkt for ledere i denne periode var som nævnt produktiviteten. Ledere frygtede en lavere produktivitet, da corona-krisen startede. Men denne bekymring blev hurtigt gjort til skamme - alle ledere i interviewene i foråret 2020 oplevede højere produktivitet end forventet. Her skal det huskes, at forventningerne måske nok var lavere end den normale produktivitet. 
Konsekvensen var, at ledere relativt hurtigt flyttede fokus væk fra produktivitet og over til andre udfordringer, først og fremmest virtuel ledelse. Virtuel ledelse er en anden øvelse end traditionel ledelse, og som vi alle ved i dag, skal et møde ledes på bestemte måder, lige fra det helt simple (husk at bruge mute-knappen) til mere komplicerede spørgsmål om hvorvidt, hvordan og hvor mange, der kan gå i dialog i et zoom-møde. For mange ledere var der tale om en meget hektisk og stresset periode, med en meget stejl læringskurve - men for mange også en meget spændende periode, hvor man i dén grad blev udfordret på ledelse og samarbejde. Særligt ledere, som før corona havde insisteret på medarbejdernes tilstedeværelse på arbejdspladsen, og som måske også havde udøvet relativt meget kontrol, var udfordret, når der nu skulle ledes på distancen.

\section{Fase 2: Eufori, kreativitet og arbejdsgloede - på trods}

I anden fase efter 3-4 uger fandt mange medarbejdere betydelig arbejdsglæde i at kreere nye og kreative løsninger på de udfordringer, som corona-krisen stillede. På plejehjemmene lykkedes det nogle steder at lære de ældre at face-time med pårørende, som nu ikke måtte besøge dem; en virksomhed, som havde mistet ordrer på plastbaserede reklameskilte, kunne meget hurtigt omlægge produktionen til at lave visirer til front-personale; et lukket museum begyndte at producere videoer, som kunne øge skolebørns appetit på at besøge museet, når det igen kunne modtage besøgende etc. Ledelsen har mange steder været mere åbne for eksperimenter og mere tolerant over for fejl, fordi man bevægede sig på ukendt grund i opgaveløsningen. Det betød, at mange medarbejdere oplevede at kunne arbejde mere frit og kreativt; når intet er helt normalt, når ledelsen er længere væk, og når opgaverne er nye, er der også større muligheder for at komme med nye og anderledes løsninger. I spørgeskemaundersøgelsen angiver $66 \%$ af de 594 HR-ledere, at medarbejderne har været i stand til at finde kreative løsninger på problemstillinger under corona-krisen - kun 4 \% er uenig heri. Men spørgeskemaundersøgelsen viser dog også, at det ikke er alle steder, ledere accepterede fejl under corona-krisen. Blandt de 594 HR-ledere angiver hver fjerde, at de er helt eller delvist enige $i$, at ledere har givet mere frirum til medarbejderne i forhold til at lave fejl. $21 \%$ er helt eller delvist uenige. Et stort mindretal - $46 \%$ - er hverken er enige eller uenige.

Samtidig optrådte ordet 'fordybelse' i mange interview. Hjemmearbejdet betød færre afbrydelser og tid til at sætte sig dybere ind i problemstillinger og undersøge baggrunden for dem. Det blev værdsat af mange medarbejdere, som før coronaen kun sjældent havde oplevet fred og tid til fordybelse - og flere fremhævede, at de på ingen måde savnede storrumskontorer, nu hvor de havde prøvet at arbejde uden at blive forstyrret af kollegers samtaler.

Et element, som fyldte en del i forårets interviews blandt især ledere, var øget opmærksomhed på betydningen af uformelle møder - altså det, der nu ikke var muligt, når medarbejdere arbejdede hjemme. Ved det uformelle møde finder vigtige udvekslinger sted, både af faglig og social karakter. Det sociale handler om at fornemme, hvordan medarbejdere og kolleger har det. Men nok så betydningsfuldt er det, at det mere eller mindre tilfældige møde ved kaffemaskinen også er produktivt. Flere mellemledere påpegede, at fordi man nu ikke mødtes ved kaffemaskinen og fik rettet små misforståelser og fejl eller fik kalibreret sagsbehandlinger, så skete der flere fejl - som i sidste instans kunne koste økonomisk og kvalitetsmæssigt.

Overordnet angiver mange ledere og medarbejdere denne periode som præget af arbejdsglæde trods udfordringerne - og i nogle tilfælde tilmed en eufori, fordi der var så stor 
frihed til at være kreativ og prøve nyt. Fasen var tillige præget af en stor fællesskabsfølelse om at løse de problemer, som krisen skabte - og dermed også betydelig fleksibilitet fra især medarbejdersiden.

\section{Fase 3: Mødet med corona-muren - (mis)trivsel}

Samtidig med, at de 14 dages nedlukning stille og roligt udvikler sig til flere måneders nedlukning henover foråret, støder stadig flere ind i corona-muren; følelsen af, at arbejde og fritid går i ét, og tingene går i ring. Flere og flere rapporterer i interviewene i den senere fase om mistrivsel, men det fordeler sig ganske forskelligt og måske ikke, som man lige havde forventet som udgangspunkt. Ganske vist har mange familier været presset, fordi der både skulle arbejdes og hjemmeskoles. Men i de samme familier er mange timers transport taget ud af ligningen, og samlet har forældre i nogle tilfælde fået 15-20 timer 'ekstra' på den konto. Transaktionsomkostninger i forbindelse med transport eller overgang fra ét møde til et andet er stærkt reducerede.

Det har tillige været muligt at lægge arbejdstiden fordelt ud over dagen. Få har i denne periode arbejdet $71 / 2$ sammenhængende timer, men fordelt arbejdstiden ud over morgen, dag og aften. Socialt har familierne trods alt haft hinanden som selskab under nedlukningen, selv om de måske nok har savnet at se venner.

Anderledes ensomme har de enlige medarbejdere været. Det kan være den fraskilte, enlige 50-årige, for hvem arbejdet er en vigtig social base. Men det kan også være den relativt nyansatte 25 -årige, som udover at mangle det sociale fællesskab også har måttet lide under ikke at kunne komme fagligt på plads på arbejdspladsen. For mange medarbejdere har det således været en ny erkendelse, hvor vigtigt arbejdet er for deres sociale liv.
Ser vi over tid på udviklingen i foråret 2020, kan man tegne en kurve over den organisatoriske energi på en typisk arbejdsplads under forårets nedlukning - inspirereret af Bruch og Vogel (2011) (figur 1).

Som kurven viser, var der et tidspunkt 4-8 uger inde i nedlukningen i foråret 2020 - hvor man mange steder oplevede en eufori over de nye udfordringer og mulighederne for at tackle dem under mere frie former. Men luften gik herefter langsomt af ballonen, og i slutningen af forårets nedlukning oplevede flere ledere, at medarbejdere tiggede om at komme på arbejde igen, uanset smitterisikoen. Det betød, at trivslen hos de hjemmearbejdende blev et opmærksomhedspunkt blandt ledere i sidste fase af nedlukningen - for hvordan kom man videre, hvordan undgik man at fortsætte ned ad kurven (C) - og kunne man komme fra B til A? Midt i disse udfordringer kom den gradvise genåbning - og mange af overvejelserne blev sat på standby.

\section{Sommeren 2020 - tid for refleksion?}

Hen mod afslutningen af første interviewrunde i foråret 2020 var der enkelte arbejdspladser, hvor man allerede var begyndt at reflektere over, hvad man skulle tage med videre organisatorisk og ledelsesmæssigt. Andre havde planer om at gennemgå sådan en proces. Men så kom den gradvise genoplukning, og fokus rettede sig mod at komme tilbage til normalen. Således viste de første interview i efteråret - inden anden nedlukning - at ingen af arbejdspladserne i interviewene systematisk havde gennemgået erfaringer fra første nedlukning. Nogle arbejdspladser havde planlagt sådan en opsamling af erfaringer, men planerne blev hurtigt glemt, da man havde fuldt fokus på at komme tilbage til normale arbejdsforhold. 
Figur 1: Organisatorisk energi under nedlukningen foråret 2020

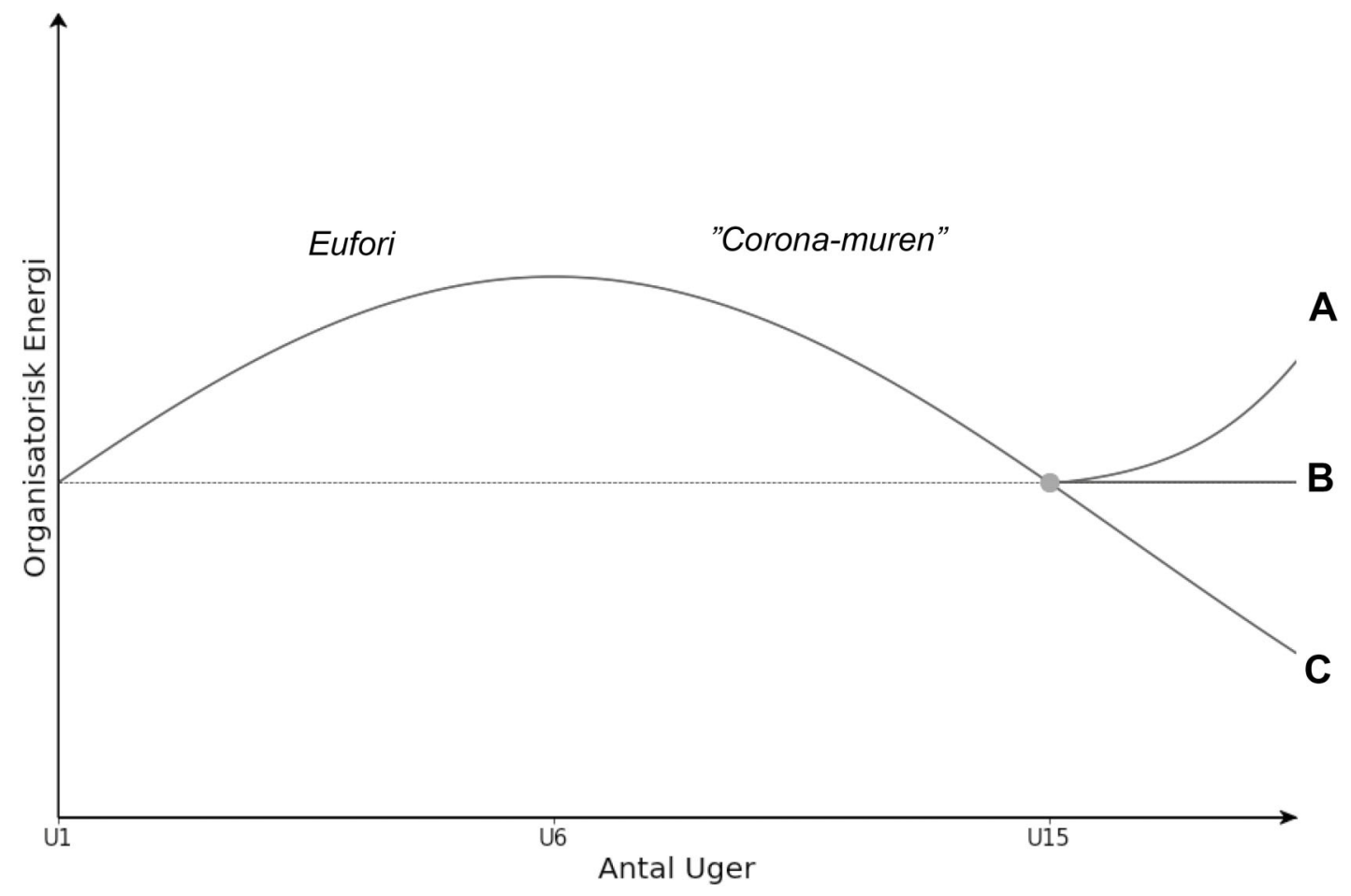

Inspireret af Bruch, H. and Vogel, B. (2011): 'Strategies for creating and sustaining organizational energy in Employment Relations', Volume 38, Issue 2, p.51-61.

Selv om kun de færreste arbejdspladser gennemgik en systematisk refleksionsproces over erfaringerne fra første nedlukning, var mange arbejdspladser alligevel bedre forberedt på anden nedlukning. Mange steder havde man nu værktøjer på plads i forhold til at tackle en ny nedlukning.

\section{Efterår 2020: Fokus på trivsel og sammenhæengskraft}

Hvor fokus i foråret 2020 i høj grad var på drift, virtuel ledelse og produktivitet, havde dette ændret sig markant ved efterårets anden nedlukning. Med den erkendelse, at produktiviteten faktisk var gået over forventning under forårets nedlukning, var dette ikke et emne i interviewene i efteråret. Men det var til gengæld medarbejdernes trivsel. De fleste ledere havde under første nedlukning bemærket, at nogle medarbejdere mistrivedes, efterhånden som nedlukningen trak ud. Derfor var det et opmærksomhedspunkt på vej ind i anden nedlukning, især fordi ledere havde oplevet, at man ikke via virtuelle medier kunne fornemme, hvordan medarbejdere og kolleger egentlig havde det, når der skulle arbejdes hjemme. Således angav 68 \% af HR-ledere, at de havde svært ved at fornemme, hvordan medarbejderne egentlig havde det, når der ikke var fysiske møder. Trivsels-billedet er imidlertid langt fra entydigt; nogle har mistrivedes ved hjemmearbejdet, men der er også en del, som har stortrivedes. 
Det meget hjemmearbejde går imidlertid ikke kun ud over trivslen. Flere ledere påpegede i efteråret 2020, at meget hjemmearbejde kan gå ud over fornemmelsen af samhørighed på arbejdspladsen. Nogle påpegede, at den sociale lim på arbejdspladsen mangler, når mange arbejder hjemme i lang tid.

"Dem, der sidder hjemme i lange perioder, de mister jo lidt den der work-family som også er den sociale lim, der giver trivsel og medarbejdertilfredshed og motivation og gloede ved at gå på job. Vi kan simpelthen se hos dem, der har voeret hjemme lidt loengere, at det har en effekt. Og det er ikke kun positivt." (Leder)

Det var tydeligvis en bekymring hos en hel del ledere, hvordan arbejdspladsen holdes sammen, når der arbejdes så massivt hjemme. Flere ledere frygtede simpelt hen for, hvad der sker med den identitet, det DNA, som arbejdspladsen har, når medarbejdere og ledelse i stort omfang arbejder hjemme.

Julefrokosten var således et tilbagevendende tema, når ledere udtrykte bekymring for sammenhængskraften, måske fordi julefrokosten er indbegrebet af den sociale lim, som fysisk samvær er for en arbejdsplads. En repræsentant for en arbejdsgiverorganisation har også hørt meget om, hvordan tabet af julefrokosten bekymrer medlemmerne:

"Man skal jo huske på, at julefrokoster er en tradition, men det er også en del af en virksomhedskultur. Det er her nogle af de grundloeggende antagelser, man har, skabes - og man har det én gang om året, hvor vi alle sammen mødes og har et eller andet til foelles." (Leder)

\section{Fremtidens arbejdsliv - hvad har vi lært af corona?}

Corona-krisen har tvunget os ud i et hidtil uset eksperiment med arbejdsliv og ledelse.
Både ledere og medarbejdere har med coronaen som prisme måttet betragte deres arbejdsliv på en ny måde - og for både ledere og medarbejdere har der været nye erkendelser af, hvad arbejde betyder, hvad ledelse består i, hvad der betyder noget på en arbejdsplads, hvad der kan gøre et arbejdsliv mere interessant, og hvilke arbejdslivsbalancer, der måske kan være fremtiden. Krisen har været irriterende - men den har også givet os en chance for at gentænke arbejdsliv og ledelse på en måde, som vi næppe nogen sinde igen får mulighed for. Alle bolde er sendt op i luften - nu handler det så om, hvordan ledelse og medarbejdere på den enkelte arbejdsplads griber boldene og forvalter denne enestående mulighed.

\section{Ledere - ny ledelsesstil?}

Ledelsers fokus ændrede sig markant fra i foråret at være på produktivitet til i efteråret at være rettet mod trivsel og sammenhængskraft på arbejdspladsen. Men det var netop også den høje produktivitet i foråret 2020, der er fundamentet for, at ledere skifter fokus og retter opmærksomheden mod andre elementer. Og for mange ledere hænger trivsel også sammen med produktivitet - som en leder siger:

"Det handler ikke kun om produktion, det handler om trivsel og dermed også om produktion."

Den høje produktivitet og kreativitet under corona har været et vink med en vognstang til ledere om, at ledelse som den har været bedrevet hidtil, godt kan tåle en revision - og det samme gælder organiseringen af arbejdet. For når medarbejderne har været så produktive, engagerede og kreative, mens de har arbejdet hjemme - hvorfor så kræve, at de skal komme på arbejde hver dag? Og 
hvor meget og hvor tæt ledelse er der brug for, når nu medarbejderne i dén grad har løftet opgaver selvstændigt under coronaen?

De ledelser, som før corona har haft den fladeste struktur og/eller har uddelegeret meget til det lokale niveau og som har haft høj grad af social kapital, er også dem, som under corona har haft nemmest ved at lede virtuelt; set-up'et var så at sige på plads. Overordnet synes ledelsesformer baseret på centraliseret decentralisering at have klaret sig bedst under corona-nedlukninger. Med det menes ledelser, som har sat de overordnet mål centralt, men ladet mellemledere og deres teams om selv at bestemme, hvordan målene nås.

Til gengæld har ledere, der tidligere har prioriteret tilstedeværelse på arbejdspladsen og/eller hierarkisk ledelse højt, måttet reflektere over deres ledelsesstil. Det betyder ikke nødvendigvis, at mere hierarkiske ledelsesformer har klaret sig dårligt under krisen. Her har ledere blot været igennem en endnu stejlere læringskurve, når de har skullet erkende, at den ledelse, de har bedrevet i en årrække, måske skal ændres i lyset af erfaringerne under corona.

Mange steder har vejen fra beslutning til implementering været kortere under corona - ikke fordi det var et bevidst valg fra ledelsen side, men fordi nye organiseringer af arbejdet under krisen fordrede det. Det er blevet vel modtaget blandt medarbejdere og indikerer, at der måske også nogle steder kunne leanes i beslutningsprocesserne og måske også i ledelsen, uden at det nødvendigvis går ud over organisation, kvalitet og produktivitet.

Samtidig bør man være opmærksom på, at nedlukninger som en undtagelsestilstand har betydet, at man mange steder har sprunget sædvanlige procedurer over for at nå målet. Det gælder ledelsesbeslutninger, som jo også ligger under ledelsesretten - men det gælder også en række processer, som har betydning for medarbejdernes arbejdsliv og samarbejde.
Som eksempler er medarbejderudviklingssamtaler mange steder blevet udsat, ligesom arbejdet i MED-udvalg, samarbejdsudvalget eller arbejdsmiljøudvalget nogle steder blev sat på stand-by - mens disse udvalg andre steder har været vigtige samarbejdspartnere i tackling af krisen på den enkelte arbejdsplads. Fx havde man ikke på nogen af de interviewede virksomheder diskuteret arbejdsmiljøforhold i forbindelse med de mange måneders hjemmearbejde $\mathrm{i}$ foråret - og kun enkelte havde taget spørgsmålet op i forbindelse med efterårets nedlukning. Nogle medarbejdere har i flere måneder arbejdet $\mathrm{i}$ familiens køkken.

Spørgsmålet er nu, hvad man på den enkelte arbejdsplads skal bevare fra corona-nedlukningerne, og hvad der skal skrottes. Hvis man som arbejdsplads - dvs. ledelse - ikke lærer af de muligheder og udfordringer, som corona-nedlukningerne har givet både ledelse og medarbejdere, så er det ikke rettidig omhu og kan skade både virksomhed og medarbejdere. Fx kan den arbejdsplads, som ikke tager denne læring alvorligt, blive taberen i kampen om den gode arbejdskraft. De arbejdspladser, der kan opfylde medarbejdernes ønsker om et fleksibelt, kreativt og indholdsrigt arbejdsliv, kan tiltrække og fastholde de bedste medarbejdere. For også medarbejdere har fået et nyt syn på, hvad det gode arbejdsliv er og vil søge mod arbejdspladser, som giver størst mulig fleksibilitet og bedst mulig arbejdslivsbalance.

\section{Medarbejdere - fordybelse og voerdscettelse af det sociale}

Det er ikke kun ledere, der har været igennem en stejl læringskurve under corona. Også mange medarbejdere er nået til nye erkendelser om deres arbejdsliv og arbejdspladsens betydning efter mange måneders hjemmearbejde. For mange medarbejdere har det været en overraskelse, hvor stor en 
betydning arbejdet har. Dels har den faglige sparring betydet meget for alle - men det sociale, at møde andre mennesker tilfældigt over kaffemaskinen og dér få både sociale og faglige input, har mange savnet meget. Mange har ikke været klar over, hvor stor en del i deres liv arbejdspladsen har, både faglig og socialt - men det er blevet tydeligt, når vi pludselig tvinges væk fra den fysiske arbejdsplads i mange måneder.

På den positive side tæller, at mange har oplevet ro og tid til fordybelse under hjemmearbejdet. Mange har også oplevet rum til kreativitet, som har givet et boost i arbejdsglæden. Det kan meget vel forventes at være betingelser, som medarbejdere vil efterspørge i fremtiden. På den måde kan corona have skabt en ny bevidsthed hos mange medarbejdere om, hvad de vil med deres arbejdsliv - og det stiller så også nye krav til ledelser.

Der er betydelig forskel på, hvor godt den enkelte medarbejder har haft det med hjemmearbejde. Nogle - særligt de introverte - har stortrivedes, mens andre har mistrivedes. Nogle har produceret (og enkelte overproduceret), når de arbejdede hjemme, mens andre har haft svært ved at få struktur på hverdagen. Og så er der nogen, der har oplevet dobbeltheden ved hjemmearbejdet. En interviewperson beskrev det således:

"Det har voeret underligt at arbejde hjemme under corona-nedlukningen. Jeg er stresset, jeg har haft tid fordybelse - men jeg er også mere afslappet."

Dette citat afspejler ganske godt, hvilken dobbelttydig periode corona-nedlukningerne har været for medarbejderne.

Hvis ledere - eller medarbejdere - fremover ønsker mere hjemmearbejde, så bliver en vigtig opgave for ledere og medarbejderne at gå i dialog om, hvem der egner sig til og trives ved at arbejde hjemme - og hvem, der ikke gør. Analyserne i dette projekt viser, at der ikke er en one-size-fits-all. Der skal altså gøres forskel på folk, når det gælder hjemmearbejdet, og arbejdets organisering skal således tilpasses både arbejdspladens og opgavens behov og den enkelte medarbejders behov.

\section{Nye arbejdslivsbalancer - tilbage til de gode gamle dage?}

Over de seneste ti år har arbejdslivsbalance været højt på dagsordenen - især i faglige organisationer og i arbejdsmiljøkredse. Det har til dels handlet om, at vi arbejder for meget - men det har også i høj grad drejet sig om, at arbejdet har haft en karakter, så stadigt flere har vanskeligt ved at sætte skarpe grænser mellem arbejdsliv og fritid.

Under corona-krisens nedlukninger har denne forståelse af adskilt arbejdsliv og fritidsliv i den grad været udfordret: Mange har arbejdet, når det har kunnet tilpasses ift. hjemmeskoling eller pasning af børn - og det betyder, at grænserne mellem arbejde og fritid for mange har været opblødt - eller ikke-eksisterende.

Det er i den sammenhæng værd at huske på, at konstruktionen med et skarpt opdelt arbejds- og fritidsliv er relativt ny - kun ca. 150 år gammel. Før industrialiseringen og vandringen fra land til by var der ikke klar forskel mellem arbejdsliv og fritid, og børnene var en integreret del af arbejdsdagen; de hjalp til med dyrene, såning og høst, og meget læring fandt sted side om side med forældrenes arbejde - ligesom mange har oplevet under corona-nedlukningerne.

Med industrialiseringen blev arbejdet adskilt fra fritiden. Arbejdet blev målt i timer og minutter og blev aflønnet i henhold til aftaler mellem arbejdsgiver og lønmodtager - ofte i en kollektiv overenskomst. Arbejdskraften blev i bogstavelig forstand kapitaliseret, og for arbejdsgiveren har det handlet om at få mest mulig arbejdskraft for lavest mulig løn, mens det for lønmodtageren har handlet om 
det modsatte. For godt 100 år siden kæmpede fagbevægelsen under parolen ' 8 timers arbejde -8 timer fritid -8 timers hvile' men parolen i sig selv siger meget tydeligt, at arbejdet er skarpt adskilt fra fritid og hvile.

Denne opdeling har været en inkarneret del af relationen mellem arbejdsgiver og arbejdstager. Men under coronaen har især familier oplevet en hidtil uset sammenblanding af arbejdsliv og fritid. Mange har arbejdet fra tidlig morgen, nu hvor transport var taget ud af ligningen, for så at sætte børn i gang med undervisning via nettet. Så tilbage til arbejde, måske frokost med børn osv. Lidt ligesom for 150 år siden. Vi har ikke data på, hvor stor en andel af lønmodtagere, der har oplevet en anderledes, bedre eller dårligere arbejdslivsbalance under coronaen. Men interviewene viser, at corona-krisen har været en øjenåbner, som har fået en del både le- dere og medarbejdere til at revurdere deres forståelse af de gode arbejdsliv.

Diskussioner om arbejdslivsbalance og det grænseløse arbejdes udfordringer har stået på $i$ årtier, med fokus på de problemer, som sammenblandingen af arbejdsliv og fritid skaber. I lyset af erfaringer fra corona-nedlukninger er spørgsmålet, om der ikke er behov for at diskutere mere åbent, om en sammenblanding af arbejdsliv og fritid nødvendigvis er et problem for alle medarbejdere - eller om der rent faktisk er nogle, for hvem et mindre opdelt arbejdsliv/fritidsliv kan skabe en bedre arbejdslivsbalance. Det emne må og bør blive centralt på arbejdspladser på vej ud af corona-krisen - og det vil være rettidig omhu, hvis ledelsen på den enkelte arbejdsplads systematisk reflekterer over, hvad man har lært af krisen, både som organisation og hvad angår den enkelte medarbejders ønsker og behov.

Steen E. Navrbjerg, lektor

FAOS - Forskningscenter for Arbejdsmarkeds- og Organisationsstudier, Københavns Universitet

e-mail: sen@faos.dk

Dana Minbaeva, professor

Institut for Strategi og Innovation, Copenhagen Business School

e-mail: dm.si@cbs.dk 